\title{
Estrogen suppresses melatonin-enhanced hyperactivation of hamster spermatozoa
}

\author{
Masakatsu FUJINOKI ${ }^{1)}$ and Gen L. TAKEI ${ }^{1)}$ \\ 1)Department of Physiology, Dokkyo Medical University, Tochigi 321-0293, Japan
}

\begin{abstract}
Hamster sperm hyperactivation is enhanced by progesterone, and this progesterone-enhanced hyperactivation is suppressed by $17 \beta$-estradiol $\left(17 \beta \mathrm{E}_{2}\right)$ and $\gamma$-aminobutyric acid (GABA). Although it has been indicated that melatonin also enhances hyperactivation, it is unknown whether melatonin-enhanced hyperactivation is also suppressed by $17 \beta \mathrm{E}_{2}$ and GABA. In the present study, melatonin-enhanced hyperactivation was significantly suppressed by $17 \beta \mathrm{E}_{2}$ but not by GABA. Moreover, suppression of melatonin-enhanced hyperactivation by $17 \beta \mathrm{E}_{2}$ occurred through non-genomic regulation via the estrogen receptor (ER). These results suggest that enhancement of hyperactivation is regulated by melatonin and $17 \beta \mathrm{E}_{2}$ through non-genomic regulation.
\end{abstract}

Key words: Estradiol, Hyperactivation, Melatonin, Non-genomic regulation, Spermatozoa

(J. Reprod. Dev. 61: 287-295, 2015)

lis. mammals, only capacitated spermatozoa can fertilize an egg. Capacitated spermatozoa generally show two major responses, known as "acrosome reaction" and "hyperactivation" [1-3]. The acrosome reaction is an exocytosis occurring at the sperm head; and is required for penetration of the zona pellucida (ZP) [1]. Hyperactivation is a modification of flagellar movement to create the driving force for penetrating the ZP [1-3]. Moreover, the ability of spermatozoa to be hyperactivated correlates with the success of in vitro fertilization [4].

It has been recently reported that hyperactivation is regulated by several hormones and transmitters (e.g., progesterone [5-10], $17 \beta$-estradiol $\left(17 \beta \mathrm{E}_{2}\right)[8,10]$, melatonin $[11,12]$, serotonin $(5-\mathrm{HT})$ [13] and $\gamma$-aminobutyric acid (GABA) [14-18]). In the hamster, progesterone, melatonin and serotonin enhance hyperactivation in a dose-dependent manner [7, 10, 11, 13]. Moreover, progesterone enhances hyperactivation through non-genomic regulation associated with a progesterone receptor (PR), phospholipase C (PLC), inositol 1,4,5-tris-phosphate receptor $\left(\mathrm{IP}_{3} \mathrm{R}\right)$, protein kinases and tyrosine phosphorylations [7, 9]. Melatonin enhances hyperactivation via melatonin receptor type 1 (MT1) [11]. Serotonin enhances hyperactivation via the $5-\mathrm{HT}_{2}$ and $5-\mathrm{HT}_{4}$ receptors [13]. In humans, progesterone and melatonin change motility parameters and enhance hyperactivation $[5,6,12]$. It has also been shown that $17 \beta \mathrm{E}_{2}$ and GABA dose-dependently suppress progesterone-enhanced hyperactivation in the hamster $[8,9,18]$. Furthermore, $17 \beta \mathrm{E}_{2}$ suppresses progesteroneenhanced hyperactivation through non-genomic regulation associated with the estrogen receptor (ER) and tyrosine dephosphorylations

Received: September 29, 2014

Accepted: April 8, 2015

Published online in J-STAGE: May 11, 2015

(C)2015 by the Society for Reproduction and Development

Correspondence: M Fujinoki (e-mail: fujinoki@dokkyomed.ac.jp)

This is an open-access article distributed under the terms of the Creative

Commons Attribution Non-Commercial No Derivatives (by-nc-nd) License

$<$ http://creativecommons.org/licenses/by-nc-nd/3.0/>.
[8]. GABA suppresses progesterone-enhanced hyperactivation via the $\mathrm{GABA}_{\mathrm{A}}$ receptor [18]. Interestingly, in humans, rams and rats, GABA increases hyperactivation via the $\mathrm{GABA}_{\mathrm{A}}$ receptor [14-17].

In hamster spermatozoa, there are three enhancers of hyperactivation: progesterone [7, 9, 10], melatonin [11] and serotonin [13]. Moreover, there are two suppressors of progesterone-enhanced hyperactivation: $17 \beta \mathrm{E}_{2}[8,10]$ and $\mathrm{GABA}[18]$. In order to understand the regulatory mechanisms of sperm hyperactivation caused by enhancers and suppressors, interactions among them need to be examined. Therefore, in the present study, we examined whether melatonin-enhanced hyperactivation of hamster spermatozoa is suppressed by $17 \beta \mathrm{E}_{2}$ and GABA.

\section{Materials and Methods}

\section{Chemicals}

Hypotaurine, (-)epinephrine, $17 \alpha$-estradiol $\left(17 \alpha \mathrm{E}_{2}\right), 17 \beta \mathrm{E}_{2}$, fluorescein isothiocyanate and bovine serum albumin (BSA)-conjugated $17 \beta \mathrm{E}_{2}\left(\mathrm{BSA}-17 \beta \mathrm{E}_{2}\right)$, GABA, melatonin, sodium taurocholate, sodium metabisulfite, and tamoxifen were purchased from Sigma-Aldrich (St Louis, MO, USA). BSA fraction V was purchased from Merck KGaA (Darmstadt, Germany). Other reagent-grade chemicals were purchased from Wako Pure Chemical Industries (Osaka, Japan).

\section{Animals and preparation of hyperactivated spermatozoa}

Spermatozoa were obtained from the posterior epididymis of sexually mature male golden hamsters (Mesocricetus auratus). The experimental plan was approved by the Animal Care and Use Committee of the Dokkyo Medical University (Experimental permission number: 0107), and the experiment was carried out according to the Guidelines for Animal Experimentation of the University.

Hyperactivated spermatozoa were prepared using the modified Tyrode's albumin lactate pyruvate (mTALP) medium [20] containing $101.02 \mathrm{mM} \mathrm{NaCl}, 2.68 \mathrm{mM} \mathrm{KCl}, 2 \mathrm{mM} \mathrm{CaCl}_{2}-2 \mathrm{H}_{2} \mathrm{O}, 1.5 \mathrm{mM}$ $\mathrm{MgCl}_{2}-6 \mathrm{H}_{2} \mathrm{O}, 360 \mu \mathrm{M} \mathrm{NaH}{ }_{2} \mathrm{PO}_{4}-2 \mathrm{H}_{2} \mathrm{O}, 35.70 \mathrm{mM} \mathrm{NaHCO}{ }_{3}, 4.5$ 
A

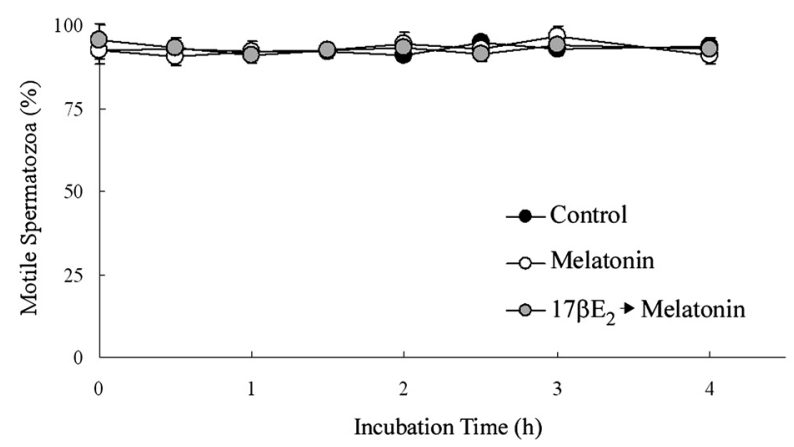

$\mathrm{C}$

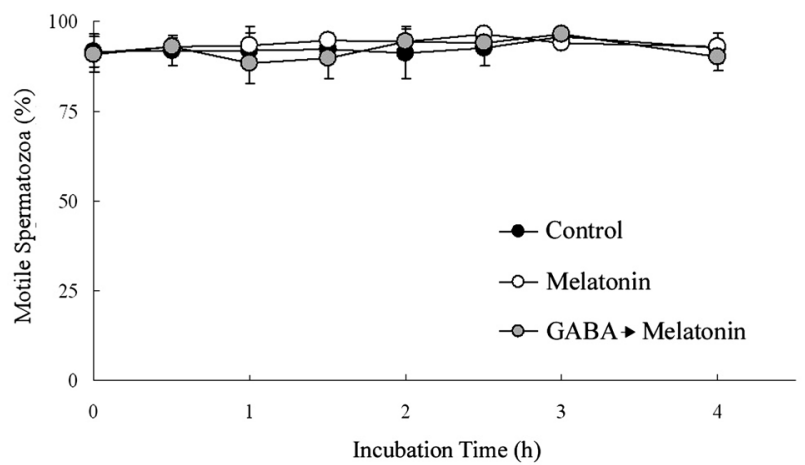

$\mathrm{B}$

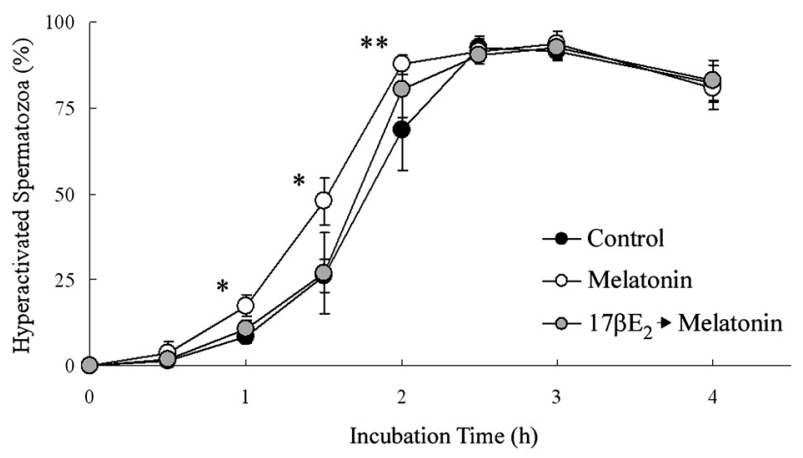

$\mathrm{D}$

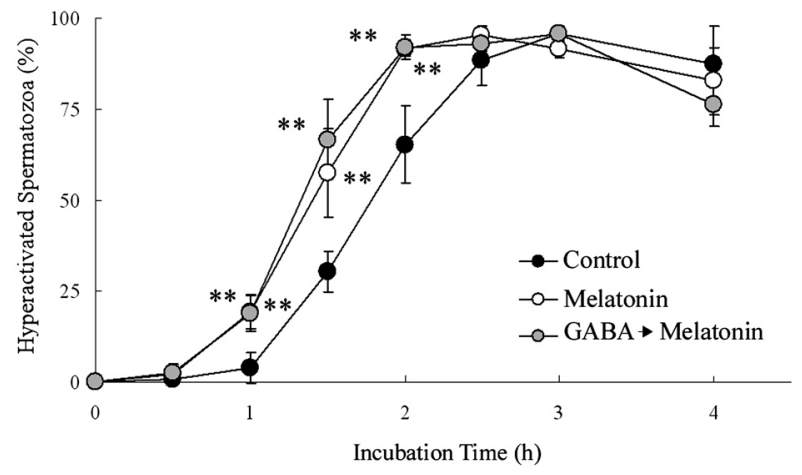

Fig. 1. Suppression of melatonin-enhanced hyperactivation by $17 \beta \mathrm{E}_{2}$ and $\mathrm{GABA}$. The percentages of motile (A, C) and hyperactivated (B, D) spermatozoa are shown for when spermatozoa were exposed to melatonin and $17 \beta \mathrm{E}_{2}(\mathrm{~A}, \mathrm{~B})$ or $\mathrm{GABA}(\mathrm{C}, \mathrm{D})$. After swim up, 17ßE $\mathrm{E}_{2}$, GABA or vehicle was added to the mTALP medium containing motile spermatozoa. After incubation for $5 \mathrm{~min}$, melatonin or vehicle was added to the same medium. Data are expressed as the mean $\pm \mathrm{SD}$. (A, B) (Control): mTALP medium with $0.2 \%$ (v/v) EtOH; (Melatonin): mTALP medium with addition of $1 \mathrm{nM}$ melatonin and $0.2 \%(\mathrm{v} / \mathrm{v}) \mathrm{EtOH} ;\left(17 \beta \mathrm{E}_{2} \rightarrow\right.$ Melatonin): mTALP medium with addition of $1 \mathrm{nM}$ melatonin, $20 \mathrm{ng} / \mathrm{ml} 17 \beta \mathrm{E}_{2}$ and $0.2 \%(\mathrm{v} / \mathrm{v}) \mathrm{EtOH}$ (C, D) (Control): mTALP medium with $0.1 \%$ (v/v) EtOH; (Melatonin): mTALP medium with addition of $1 \mathrm{nM}$ melatonin and $0.1 \%$ (v/v) EtOH; (GABA $\rightarrow$ Melatonin): mTALP medium with addition of $1 \mathrm{nM}$ melatonin, $5 \mu \mathrm{M}$ GABA and $0.1 \%(\mathrm{v} / \mathrm{v})$ EtOH. * Significant difference compared with "Control" and "17ß $\mathrm{E}_{2} \rightarrow$ Melatonin" $(\mathrm{P}<0.05)$. ${ }^{* *}$ Significant difference compared with "Control" $(\mathrm{P}<0.05)$. GABA, $\gamma$-aminobutyric acid; $17 \beta \mathrm{E}_{2}, 17 \beta$-estradiol; EtOH, ethanol; mTALP medium, modified Tyrode's albumin lactate pyruvate medium.

mM D-glucose, $90 \mu \mathrm{M}$ sodium pyruvate, $9 \mathrm{mM}$ sodium lactate, 500 $\mu \mathrm{M}$ hypotaurine, $50 \mu \mathrm{M}$ (-)epinephrine, $200 \mu \mathrm{M}$ sodium taurocholate, $5.26 \mu \mathrm{M}$ sodium metabisulfite, $0.05 \%(\mathrm{w} / \mathrm{v})$ streptomycin sulfate, $0.05 \%(\mathrm{w} / \mathrm{v})$ potassium penicillin $\mathrm{G}$ and $15 \mathrm{mg} / \mathrm{ml} \mathrm{BSA}(\mathrm{pH} 7.4$ at $37 \mathrm{C}$ under $5 \%(\mathrm{v} / \mathrm{v}) \mathrm{CO}_{2}$ in air) according to the method described previously [19]. A drop $(\sim 5 \mu \mathrm{l})$ of posterior epididymal spermatozoa was placed in a culture dish (diameter, $35 \mathrm{~mm}$ ) with $3 \mathrm{ml}$ of the mTALP medium, followed by incubation at $37 \mathrm{C}$ for $5 \mathrm{~min}$ to allow spermatozoa to swim up. All of the mTALP medium containing motile spermatozoa was placed in a new culture dish and incubated for $4 \mathrm{~h}$ at $37 \mathrm{C}$ under $5 \%(\mathrm{v} / \mathrm{v}) \mathrm{CO}_{2}$ in air to allow hyperactivation to occur. As stock solutions, melatonin $(1 \mu \mathrm{M}), 17 \alpha \mathrm{E}_{2}(20 \mu \mathrm{g} / \mathrm{ml})$ and $17 \beta \mathrm{E}_{2}(20 \mu \mathrm{g} / \mathrm{ml})$ were dissolved in ethanol; tamoxifen was dissolved at $1 \mathrm{mM}$ in dimethyl sulfoxide; and GABA $(5 \mathrm{mM})$ and BSA- $\mathrm{E}_{2}(7.4 \mu \mathrm{M})$ were dissolved in pure water. GABA, $17 \alpha \mathrm{E}_{2}, 17 \beta \mathrm{E}_{2}$, tamoxifen or vehicle was added to the mTALP medium after swim up, and after $5 \mathrm{~min}$ of incubation, melatonin or vehicle was added to the mTALP medium (Figs. 1, 2, 3A, 3B, 5A, 5B). Tamoxifen or vehicle was added to the mTALP medium after swim up, and after 5 min incubation, $17 \beta \mathrm{E}_{2}, \mathrm{BSA}-17 \mathrm{E}_{2}$ or vehicle was added to the mTALP medium again. After additional incubation for $5 \mathrm{~min}$, melatonin or vehicle was added to the mTALP medium (Figs. 3C, $3 \mathrm{D}, 4)$. Mixtures of $17 \beta \mathrm{E}_{2}$ and melatonin or vehicle were added to the mTALP medium after swim up (Figs. 5C, 5D). Melatonin or vehicle was added to the mTALP medium after swim up, and after $5 \mathrm{~min}$ of incubation, $17 \beta \mathrm{E}_{2}$ or vehicle was added to the mTALP medium (Figs. 5E, 5F). In all experiments, the maximal concentration of vehicle was $0.3 \%$ by volume.

\section{Measurement of the percentage of hyperactivated spermatozoa}

The percentage of hyperactivated spermatozoa was measured according to the method described previously [19]. Motile spermatozoa were recorded on videotape using a phase-contrast illumination unit attached to a microscope (IX70, Olympus, Tokyo, Japan) with a CCD camera (Progressive 3 CCD, Sony, Tokyo, Japan) and a small $\mathrm{CO}_{2}$ incubator (MI-IBC, Olympus). Each observation was performed 
A

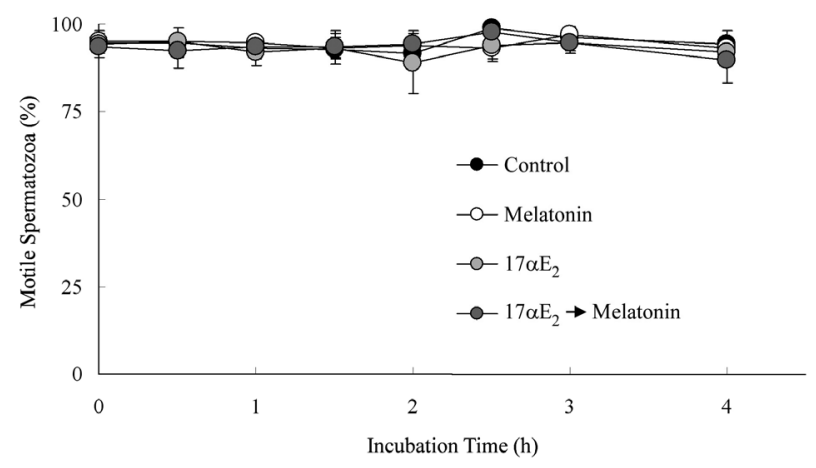

B

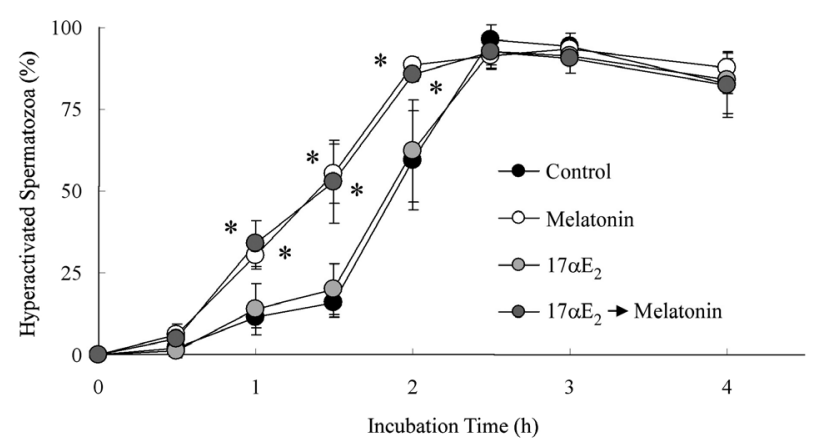

Fig. 2. Effect of $17 \alpha \mathrm{E}_{2}$ on melatonin-enhanced hyperactivation. The percentages of motile (A) and hyperactivated (B) spermatozoa are shown for when spermatozoa were exposed to melatonin and $17 \alpha \mathrm{E}_{2}$. After swim up, $17 \alpha \mathrm{E}_{2}$ or vehicle was added to the mTALP medium containing motile spermatozoa. After incubation for $5 \mathrm{~min}$, melatonin or vehicle was added to the same medium. Data are expressed as the mean $\pm \mathrm{SD}$. (Control): mTALP medium with $0.2 \%(\mathrm{v} / \mathrm{v})$ EtOH; (Melatonin): mTALP medium with $1 \mathrm{nM}$ melatonin and $0.2 \%(\mathrm{v} / \mathrm{v}) \mathrm{EtOH} ;\left(17 \alpha \mathrm{E}_{2}\right)$ : mTALP medium with $20 \mathrm{ng} / \mathrm{ml} 17 \alpha \mathrm{E}_{2}$ and $0.2 \%(\mathrm{v} / \mathrm{v}) \mathrm{EtOH} ;\left(17 \alpha \mathrm{E}_{2} \rightarrow\right.$ Melatonin): mTALP medium with $1 \mathrm{nM}$ melatonin, $20 \mathrm{ng} / \mathrm{ml} 17 \alpha \mathrm{E}_{2}$ and $0.2 \%$ (v/v) EtOH. * Significant difference compared with "Control" and "17 $\alpha \mathrm{E}_{2}$ " $(\mathrm{P}<0.05) .17 \alpha \mathrm{E}_{2}, 17 \alpha$-estradiol; EtOH, ethanol; mTALP medium, modified Tyrode's albumin lactate pyruvate medium.

at $37 \mathrm{C}$, recorded for $2 \mathrm{~min}$, and analyzed by slow-motion playback and manual counting of the numbers of total spermatozoa and hyperactivated spermatozoa in four different fields per point of analysis. The analysis was done in a blinded manner. Motile spermatozoa that exhibited asymmetric and whiplash flagellar movement and a circular and/or octagonal swimming locus were defined as hyperactivated $[3,21]$. The percentage of motile spermatozoa was defined as the number of motile spermatozoa / total number of spermatozoa $\times 100$ $(\%)$. The percentage of hyperactivated spermatozoa was defined as the number of hyperactivated spermatozoa / total number of spermatozoa $\times 100(\%)$. One hamster was used per experiment, and experiments were repeated four times.

\section{Statistical analysis}

Data are expressed as the mean \pm standard deviation (SD). Statistical analysis was carried out using Tukey's test of analysis of variance. $\mathrm{P}<0.05$ was considered significantly different.

\section{Results}

\section{Effects of $17 \beta E_{2}$ and $G A B A$ on melatonin-enhanced hyperactivation}

We examined whether melatonin-enhanced hyperactivation is suppressed by $17 \beta \mathrm{E}_{2}$ and $\mathrm{GABA}$ in a manner similar to progesteroneenhanced hyperactivation $[8,18]$. After swim up, $20 \mathrm{ng} / \mathrm{ml} 17 \beta \mathrm{E}_{2}$ or $5 \mu \mathrm{M}$ GABA was added to the mTALP medium containing motile spermatozoa, and after additional incubation for $5 \mathrm{~min}, 1 \mathrm{nM}$ melatonin was added to the same medium. After supplementation with $1 \mathrm{nM}$ melatonin, spermatozoa were incubated for $4 \mathrm{~h}$ in order to induce hyperactivation. As shown in Fig. 1A, the percentage of motile spermatozoa was not affected by addition of $1 \mathrm{nM}$ melatonin and $20 \mathrm{ng} / \mathrm{ml} 17 \beta \mathrm{E}_{2}$ when spermatozoa were exposed to $1 \mathrm{nM}$ melatonin after exposure to $17 \beta \mathrm{E}_{2}$. In contrast, as shown in Fig. $1 \mathrm{~B}$, melatonin-enhanced hyperactivation was significantly suppressed by $20 \mathrm{ng} / \mathrm{ml} 17 \beta \mathrm{E}_{2}$. After incubation for 1 or $1.5 \mathrm{~h}$, melatoninenhanced hyperactivation was significantly suppressed by $17 \beta \mathrm{E}_{2}(1$ h, Melatonin: $17.4 \% \pm 3.17,17 \beta \mathrm{E}_{2} \rightarrow$ Melatonin: $10.67 \% \pm 2.45$; 1.5 h, Melatonin: $47.89 \% \pm 6.86,17 \beta \mathrm{E}_{2} \rightarrow$ Melatonin: $26.98 \% \pm$ 11.72 ) but not significantly suppressed by $17 \beta \mathrm{E}_{2}$ after incubation for $2 \mathrm{~h}$. GABA did not affect the percentages of motile spermatozoa, hyperactivated spermatozoa and melatonin-enhanced hyperactivation (Figs. 1C, 1D).

Estradiol consists of $17 \alpha \mathrm{E}_{2}$ and $17 \beta \mathrm{E}_{2}$. Generally, $17 \alpha \mathrm{E}_{2}$ is a stereoisomer of $17 \beta \mathrm{E}_{2}$ and is at least 200 -fold less active as a hormone $[22,23]$. After swim up, $20 \mathrm{ng} / \mathrm{ml} 17 \alpha \mathrm{E}_{2}$ was added to the mTALP medium containing motile spermatozoa. After additional incubation for $5 \mathrm{~min}, 1 \mathrm{nM}$ melatonin was added to the same medium. After supplementation with $1 \mathrm{nM}$ melatonin, spermatozoa were incubated for $4 \mathrm{~h}$. As shown in Fig. 2, $20 \mathrm{ng} / \mathrm{ml} 17 \alpha \mathrm{E}_{2}$ did not affect the percentages of motile spermatozoa, hyperactivated spermatozoa and melatonin-enhanced hyperactivation.

\section{Effect of tamoxifen on suppression of melatonin-enhanced hyperactivation by $17 \beta E_{2}$}

Because melatonin-enhanced hyperactivation was suppressed by $17 \beta \mathrm{E}_{2}$ (Fig. 1), we examined whether the mechanism acted via the ER. In order to examine whether the ER was associated with suppression of melatonin-enhanced hyperactivation caused by $17 \beta \mathrm{E}_{2}$, we used tamoxifen, which is a popular ER antagonist [24-26]. It was reported that several micromoles of tamoxifen acted as an ER antagonist [27-29], although a high concentration of tamoxifen inhibited protein kinase $\mathrm{C}(\mathrm{PKC})$ in some cases [30, 31]. In a previous study [8], $1 \mu \mathrm{M}$ tamoxifen inhibited only suppression of progesterone-enhanced hyperactivation caused by $17 \beta \mathrm{E}_{2}$. After swim up in the present study, $1 \mu \mathrm{M}$ tamoxifen was added to the mTALP medium containing motile spermatozoa, and after additional incubation for $5 \mathrm{~min}, 1 \mathrm{nM}$ melatonin was added to the same medium. After supplementation with $1 \mathrm{nM}$ melatonin, spermatozoa were incubated for $4 \mathrm{~h}$. As shown in Figs. 3A and 3B, $1 \mu \mathrm{M}$ tamoxifen did not affect the percentages of motile spermatozoa, hyperactivated spermatozoa and melatonin-enhanced hyperactivated spermatozoa. 
A

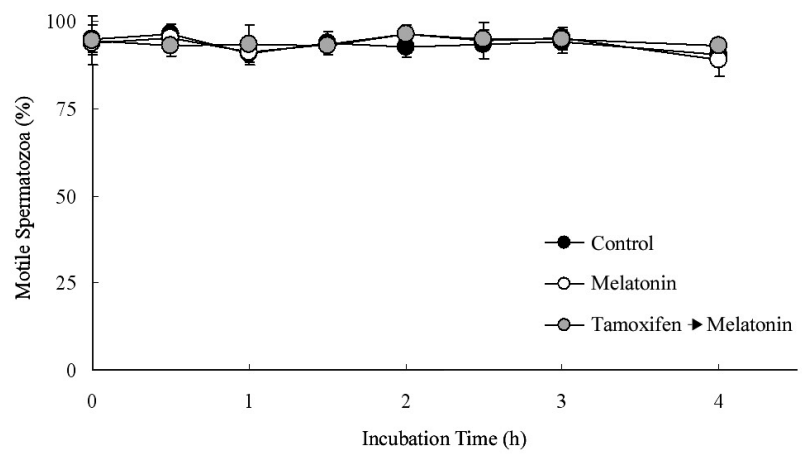

C

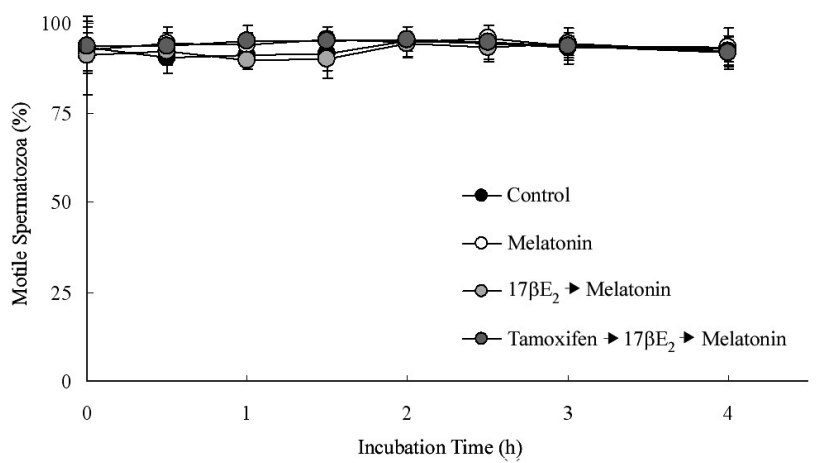

B

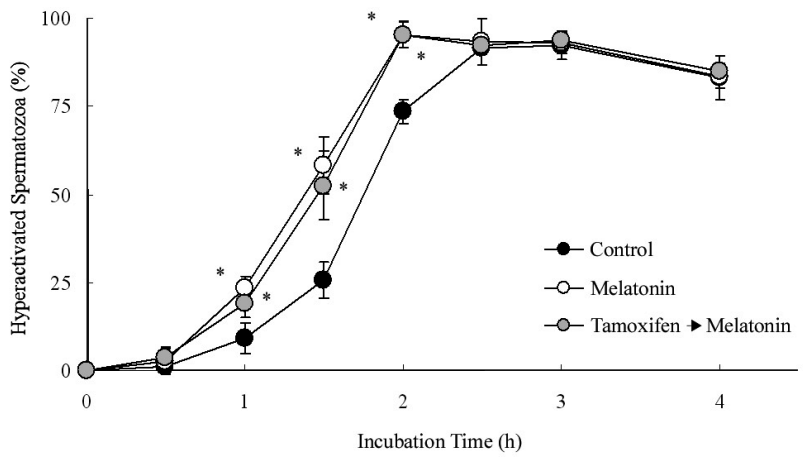

$\mathrm{D}$

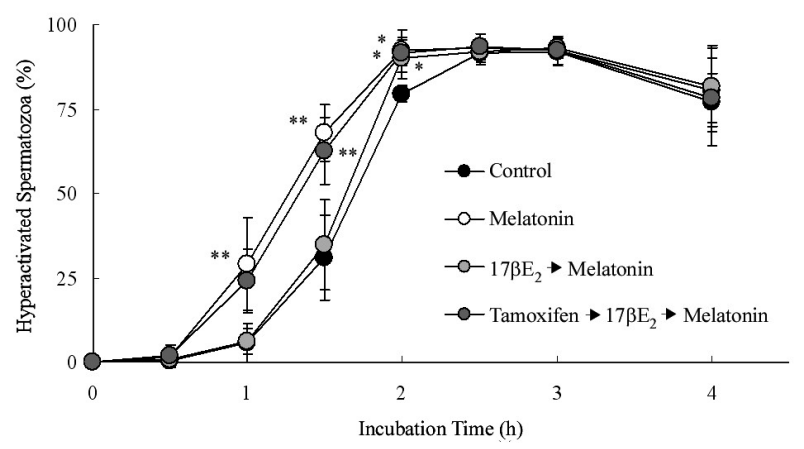

Fig. 3. Inhibition of suppression of melatonin-enhanced hyperactivation by $17 \beta \mathrm{E}_{2}$. The percentages of motile (A, C) and hyperactivated (B, D) spermatozoa are shown (A, B) for when spermatozoa were exposed to melatonin and tamoxifen, and $(\mathrm{C}, \mathrm{D})$ for when spermatozoa were exposed to melatonin, $17 \beta \mathrm{E}_{2}$ and tamoxifen. In A and B, after swim up, tamoxifen or vehicle was added to the mTALP medium containing motile spermatozoa. After incubation for $5 \mathrm{~min}$, melatonin or vehicle was added to the same medium. In $\mathrm{C}$ and $\mathrm{D}$, after swim up, tamoxifen or vehicle was added to the mTALP medium containing motile spermatozoa. After incubation for $5 \mathrm{~min}, 17 \beta \mathrm{E}_{2}$ or vehicle was added to the same medium. After incubation for 5 min again, melatonin or vehicle was added to the same medium. Data are expressed as the mean \pm SD. (A, B) (Control): mTALP medium with $0.1 \%(\mathrm{v} / \mathrm{v})$ EtOH and $0.1 \%$ (v/v) DMSO; (Melatonin): mTALP medium with addition of $1 \mathrm{nM}$ melatonin, $0.1 \%$ (v/v) EtOH and $0.1 \%$ (v/v) DMSO; (Tamoxifen $\rightarrow$ Melatonin): mTALP medium with addition of $1 \mathrm{nM}$ melatonin, $1 \mu \mathrm{M}$ tamoxifen, $0.1 \%(\mathrm{v} / \mathrm{v})$ EtOH and $0.1 \%$ (v/v) DMSO. (C, D) (Control): mTALP medium with $0.2 \%(\mathrm{v} / \mathrm{v}) \mathrm{EtOH}$ and $0.1 \%$ (v/v) DMSO; (Melatonin): mTALP medium with addition of $1 \mathrm{nM}$ melatonin, $0.2 \%$ $(\mathrm{v} / \mathrm{v}) \mathrm{EtOH}$ and $0.1 \%(\mathrm{v} / \mathrm{v})$ DMSO; $\left(17 \beta \mathrm{E}_{2} \rightarrow\right.$ Melatonin): mTALP medium with addition of $1 \mathrm{nM}$ melatonin, $20 \mathrm{ng} / \mathrm{ml} 17 \beta \mathrm{E}_{2}, 0.2 \%(\mathrm{v} / \mathrm{v}) \mathrm{EtOH}$ and $0.1 \%$ (v/v) DMSO; (Tamoxifen $\rightarrow 17 \beta \mathrm{E}_{2} \rightarrow$ Melatonin): mTALP medium with addition of $1 \mathrm{nM}$ melatonin, $20 \mathrm{ng} / \mathrm{ml} 17 \beta \mathrm{E}_{2}, 1 \mu \mathrm{M}$ tamoxifen, $0.2 \%(\mathrm{v} / \mathrm{v})$ EtOH and $0.1 \%(\mathrm{v} / \mathrm{v}) \mathrm{DMSO}$ * Significant difference compared with "Control" $(\mathrm{P}<0.05)$. ** Significant difference compared with "Control" and " $17 \beta \mathrm{E}_{2} \rightarrow$ Melatonin" $(\mathrm{P}<0.05)$. DMSO, dimethyl sulfoxide; $17 \beta \mathrm{E}_{2}, 17 \beta$-estradiol; EtOH, ethanol; mTALP medium, modified Tyrode's albumin lactate pyruvate medium.

After swim up, $1 \mu \mathrm{M}$ tamoxifen was added to the mTALP medium containing motile spermatozoa, and after additional incubation for $5 \mathrm{~min}, 20 \mathrm{ng} / \mathrm{ml} 17 \beta \mathrm{E}_{2}$ was added to the same medium. After additional incubation for $5 \mathrm{~min}$ again, $1 \mathrm{nM}$ melatonin was added to the same medium. After supplementation with $1 \mathrm{nM}$ melatonin, spermatozoa were incubated for $4 \mathrm{~h}$. As shown in Figs. 3C and 3D, tamoxifen significantly inhibited suppression of melatonin-enhanced hyperactivation by $17 \beta \mathrm{E}_{2}$ after incubation for 1 or $1.5 \mathrm{~h}(1 \mathrm{~h}$, Melatonin: $28.94 \% \pm 13.64,17 \beta \mathrm{E}_{2} \rightarrow$ Melatonin: $6.01 \% \pm 3.81$, Tamoxifen $\rightarrow 17 \beta \mathrm{E}_{2} \rightarrow$ Melatonin: $23.94 \% \pm 9.52 ; 1.5$ h, Melatonin: $67.89 \% \pm 8.37,17 \beta \mathrm{E}_{2} \rightarrow$ Melatonin: $34.71 \% \pm 13.41$, Tamoxifen $\rightarrow 17 \beta \mathrm{E}_{2} \rightarrow$ Melatonin: $62.57 \% \pm 9.77$ ), but it did not affect the percentage of motile spermatozoa.

\section{Non-genomic suppression of melatonin-enhanced hyperactivation by $17 \beta E_{2}$}

Because $17 \beta \mathrm{E}_{2}$ suppresses progesterone-enhanced hyperactivation through non-genomic regulation via the membrane ER [8], we examined whether melatonin-enhanced hyperactivation was also suppressed by $17 \beta \mathrm{E}_{2}$ through non-genomic regulation using BSA-17 $\beta E_{2}$, which binds only to the membrane ER and not to the

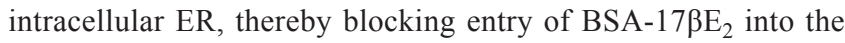
cell $[32,33]$.

After swim up, $1 \mu \mathrm{M}$ tamoxifen was added to the mTALP medium containing motile spermatozoa, and after incubation for $5 \mathrm{~min}, 7.4 \mathrm{nM}$ BSA-17ßE $\mathrm{E}_{2}$, which is converted into approximately $20 \mathrm{ng} / \mathrm{ml} 17 \beta \mathrm{E}_{2}$, was added to the medium. After additional incubation for $5 \mathrm{~min}$ again, $1 \mathrm{nM}$ melatonin was added to the medium. After supplementation with $1 \mathrm{nM}$ melatonin, spermatozoa were incubated for $4 \mathrm{~h}$. As shown in Fig. 
A

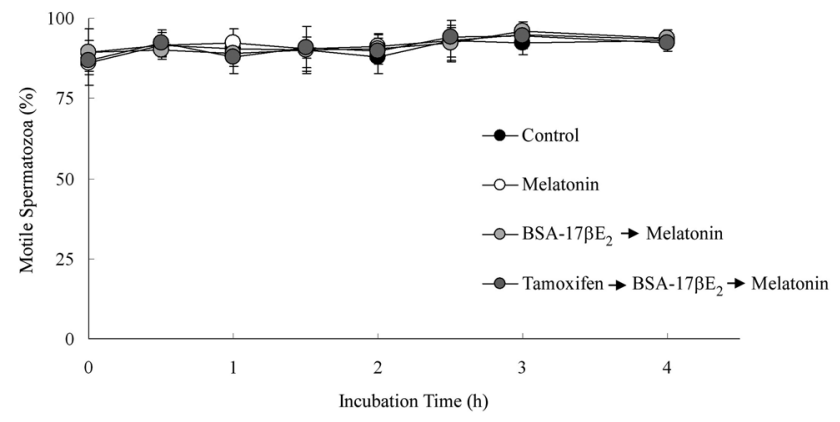

B

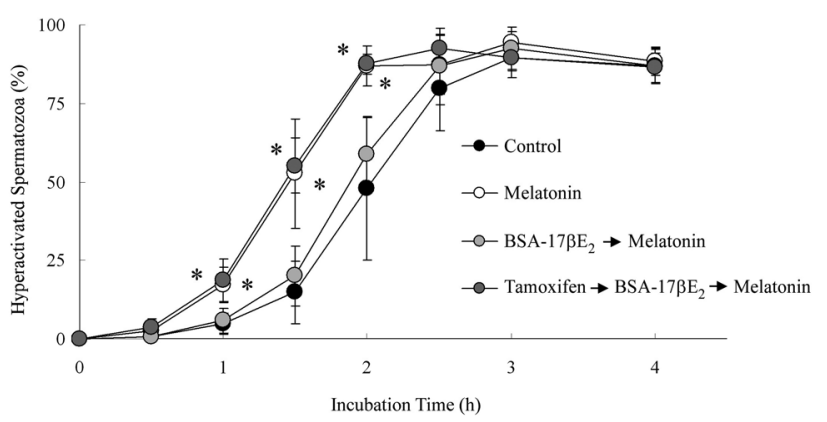

Fig. 4. Non-genomic suppression of melatonin-enhanced hyperactivation by $17 \beta \mathrm{E}_{2}$. The percentages of motile (A) and hyperactivated (B) spermatozoa are shown for when spermatozoa were exposed to melatonin, BSA-17ß $\mathrm{E}_{2}$ and tamoxifen. After swim up, tamoxifen or vehicle was added to the mTALP medium containing motile spermatozoa. After incubation for $5 \mathrm{~min}, \mathrm{BSA}-17 \beta \mathrm{E}_{2}$ or vehicle was added to the same medium. After incubation for 5 min again, melatonin or vehicle was added to the same medium. Data are expressed as the mean $\pm \mathrm{SD}$. (Control): mTALP medium with $0.1 \%(\mathrm{v} / \mathrm{v})$ EtOH and $0.1 \%(\mathrm{v} / \mathrm{v})$ DMSO; (Melatonin): mTALP medium with addition of $1 \mathrm{nM}$ melatonin, $0.1 \%(\mathrm{v} / \mathrm{v}) \mathrm{EtOH}$ and $0.1 \%(\mathrm{v} / \mathrm{v})$ DMSO; (BSA-17ß $\mathrm{E}_{2} \rightarrow$ Melatonin): mTALP medium with addition of $1 \mathrm{nM}$ melatonin, $7.4 \mathrm{nM} \mathrm{BSA}-17 \beta \mathrm{E}_{2}, 0.1 \%(\mathrm{v} / \mathrm{v})$ EtOH and 0.1\% (v/v) DMSO; (Tamoxifen $\rightarrow$ BSA-17ßE $\mathrm{B}_{2} \rightarrow$ Melatonin): mTALP medium with addition of $1 \mathrm{nM}$ melatonin, $7.4 \mathrm{nM}$ BSA-17ß $\mathrm{E}_{2}, 1 \mu \mathrm{M}$ tamoxifen, $0.1 \%(\mathrm{v} / \mathrm{v}) \mathrm{EtOH}$ and $0.1 \%$ (v/v) DMSO. * Significant difference compared with "Control" and "BSA-17ß $\mathrm{E}_{2} \rightarrow$ Melatonin" $(\mathrm{P}<0.05)$. DMSO, dimethyl sulfoxide; $17 \beta \mathrm{E}_{2}$, $17 \beta$-estradiol; EtOH, ethanol; $\mathrm{BSA}-17 \beta \mathrm{E}_{2}$, fluorescein isothiocyanate and bovine serum albumin (BSA)conjugated $17 \beta \mathrm{E}_{2}$; mTALP medium, modified Tyrode's albumin lactate pyruvate medium.

$4 \mathrm{~A}, \mathrm{BSA}-17 \beta \mathrm{E}_{2}$ did not affect the percentage of motile spermatozoa. In contrast, $\mathrm{BSA}-17 \beta \mathrm{E}_{2}$ significantly suppressed melatonin-enhanced hyperactivation after incubation for $1,1.5$ or $2 \mathrm{~h}(1 \mathrm{~h}$, Melatonin: $17.31 \% \pm 5.42, \mathrm{BSA}-17 \beta \mathrm{E}_{2} \rightarrow$ Melatonin: $5.82 \% \pm 3.74 ; 1.5 \mathrm{~h}$, Melatonin: $52.72 \% \pm 17.39$, BSA-17 $\beta \mathrm{E}_{2} \rightarrow$ Melatonin: $20.06 \% \pm$

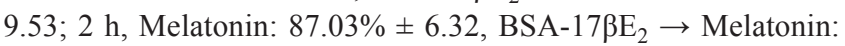
$58.87 \% \pm 12.08)$. Moreover, suppression of melatonin-enhanced

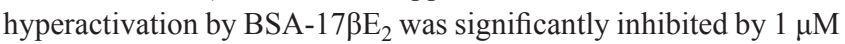
tamoxifen as in the case of $17 \beta \mathrm{E}_{2}\left(1 \mathrm{~h}\right.$, Tamoxifen $\rightarrow \mathrm{BSA}^{-17} \beta \mathrm{E}_{2}$ $\rightarrow$ Melatonin: $18.61 \% \pm 6.87 ; 1.5 \mathrm{~h}$, Tamoxifen $\rightarrow \mathrm{BSA}^{-17} \beta \mathrm{E}_{2} \rightarrow$ Melatonin: $55.11 \% \pm 8.85 ; 1.5 \mathrm{~h}$, Tamoxifen $\rightarrow \mathrm{BSA}^{-17} \beta \mathrm{E}_{2} \rightarrow$
Melatonin: $87.54 \% \pm 3.24)$.

\section{Dose-dependent effect of $17 \beta E_{2}$ on melatonin-enhanced hyperactivation}

In the next step, we examined whether $17 \beta \mathrm{E}_{2}$ suppressed melatoninenhanced hyperactivation in a dose-dependent manner (Fig. 5) because our previous studies $[8,10]$ reported that progesterone-enhanced hyperactivation was dose dependently suppressed by $17 \beta \mathrm{E}_{2}$.

Firstly, we observed sperm movement which were beforehand exposed to estrogen (Figs. 5A and 5B). After swim up, $2 \mathrm{pg} / \mathrm{ml}$ to $20 \mathrm{ng} / \mathrm{ml} 17 \beta \mathrm{E}_{2}$ were added to the mTALP medium containing motile spermatozoa, and after additional incubation for $5 \mathrm{~min}, 1 \mathrm{nM}$ melatonin was added to the medium. After supplementation with $1 \mathrm{nM}$ melatonin, spermatozoa were incubated for $4 \mathrm{~h}$. As shown in Fig. $5 \mathrm{~A}, 17 \beta \mathrm{E}_{2}$ did not affect the percentage of motile spermatozoa at the concentration tested. By contrast, $17 \beta \mathrm{E}_{2}$ significantly suppressed melatonin-enhanced hyperactivation in a dose-dependent manner (Fig. 5B). After incubation for $1 \mathrm{~h}, 200 \mathrm{pg} / \mathrm{ml}$ to $20 \mathrm{ng} / \mathrm{ml}$ $17 \beta \mathrm{E}_{2}$ significantly suppressed melatonin-enhanced hyperactivation (Melatonin: $21.38 \% \pm 3.49,200 \mathrm{pg} / \mathrm{ml}_{17} \mathrm{E}_{2} \rightarrow$ Melatonin: $6.32 \% \pm$

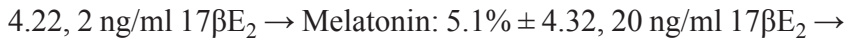
Melatonin: $4.77 \% \pm 5.06$ ), whereas $2 \mathrm{pg} / \mathrm{ml} 17 \beta \mathrm{E}_{2}$ did not. Moreover, the effect of $20 \mathrm{pg} / \mathrm{ml} 17 \beta \mathrm{E}_{2}$ was also not significantly different compared with the control and melatonin (Control: $4.48 \% \pm 4.08$, Melatonin: $21.38 \% \pm 3.49,20 \mathrm{pg} / \mathrm{ml} 17 \beta \mathrm{E}_{2} \rightarrow$ Melatonin: $13.85 \%$ \pm 6.59 ). After incubation for $1.5 \mathrm{~h}, 20 \mathrm{ng} / \mathrm{ml} 17 \beta \mathrm{E}_{2}$ significantly suppressed melatonin-enhanced hyperactivation (Melatonin: $83.34 \%$

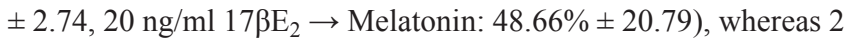

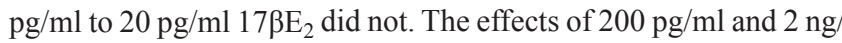
$\mathrm{ml} 17 \beta \mathrm{E}_{2}$ were not significantly different compared with the control and melatonin (Control: $45.95 \% \pm 23.47$, Melatonin: $83.34 \% \pm 2.74$, $200 \mathrm{pg} / \mathrm{ml} 17 \beta \mathrm{E}_{2} \rightarrow$ Melatonin: $58.85 \% \pm 14.95,2 \mathrm{ng} / \mathrm{ml} 17 \beta \mathrm{E}_{2} \rightarrow$ Melatonin: $52.13 \% \pm 18.52$ ). After incubation for $2 \mathrm{~h}, 17 \beta \mathrm{E}_{2}$ did not suppress melatonin-enhanced hyperactivation.

In the next step, hamster spermatozoa were exposed to the mixture of $1 \mathrm{nM}$ melatonin and $2 \mathrm{pg} / \mathrm{ml}$ to $20 \mathrm{ng} / \mathrm{ml} 17 \beta \mathrm{E}_{2}$ after swim up and incubated for $4 \mathrm{~h}$ in order to mimic the physiological action of estrogen in the spermatozoa (Figs. 5C and 5D). As shown in Fig. $5 \mathrm{C}, 17 \beta \mathrm{E}_{2}$ did not affect the percentage of motile spermatozoa. By contrast, $17 \beta \mathrm{E}_{2}$ suppressed melatonin-enhanced hyperactivation in a dose-dependent manner (Fig. 5D). After incubation for $1 \mathrm{~h}$, melatonin slightly enhanced hyperactivation, but the enhancement of hyperactivation caused by melatonin was not significantly different compared with the control (Control: $9.65 \% \pm 2.84$, Melatonin: $25.87 \% \pm 8.86$ ). Moreover, $20 \mathrm{pg} / \mathrm{ml}$ to $20 \mathrm{ng} / \mathrm{ml} 17 \beta \mathrm{E}_{2}$ slightly suppressed the effect of melatonin, but the level of hyperactivation was not significantly different compared with that with melatonin only

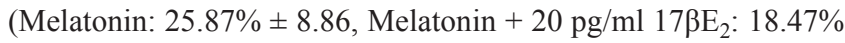
\pm 11.8 , Melatonin $+200 \mathrm{pg} / \mathrm{ml}_{17} \mathrm{E}_{2}: 13.99 \% \pm 7.39$, Melatonin

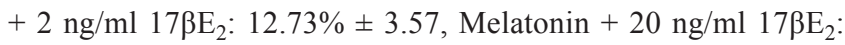
$10.99 \% \pm 6.28$ ). After incubation for $1.5 \mathrm{~h}, 2 \mathrm{ng} / \mathrm{ml}$ and $20 \mathrm{ng} / \mathrm{ml}$ $17 \beta \mathrm{E}_{2}$ significantly suppressed melatonin-enhanced hyperactivation (Melatonin: $65.55 \% \pm 2.98$, Melatonin $+2 \mathrm{ng} / \mathrm{ml} 17 \beta \mathrm{E}_{2}: 36.68 \% \pm$ 9.41 , Melatonin $\left.+20 \mathrm{ng} / \mathrm{ml} 17 \beta \mathrm{E}_{2}: 39.35 \% \pm 7.56\right)$, whereas $2 \mathrm{pg} /$ $\mathrm{ml}$ to $200 \mathrm{pg} / \mathrm{ml} 17 \beta \mathrm{E}_{2}$ did not. After incubation for $2 \mathrm{~h}, 17 \beta \mathrm{E}_{2}$ did not suppress melatonin-enhanced hyperactivation. 
A

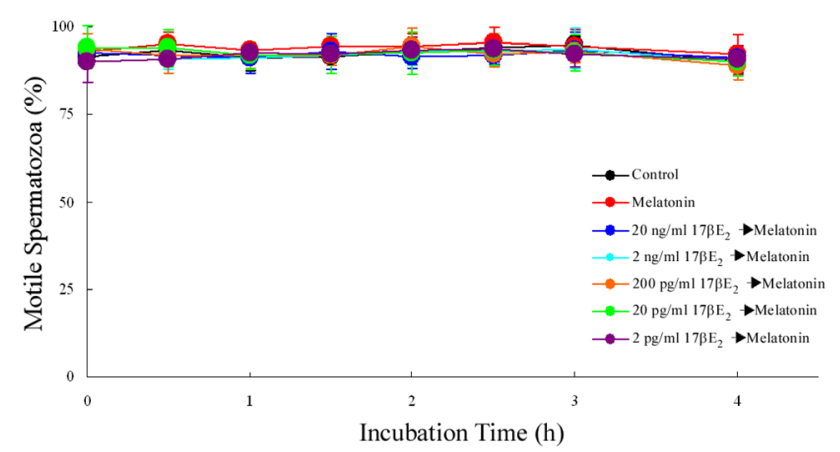

C

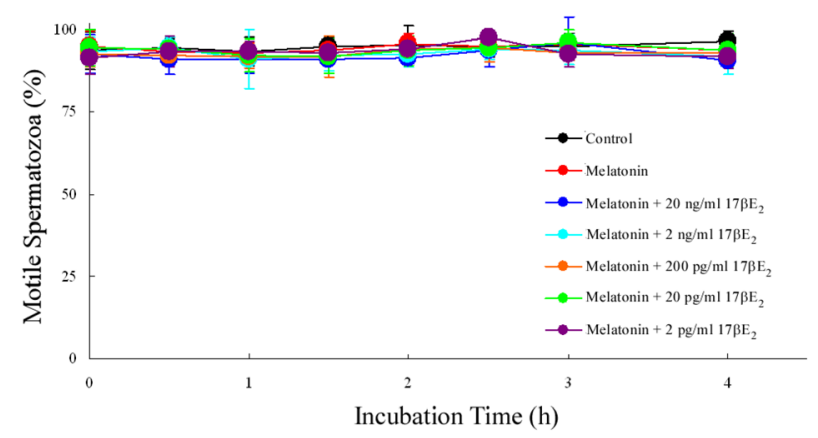

E

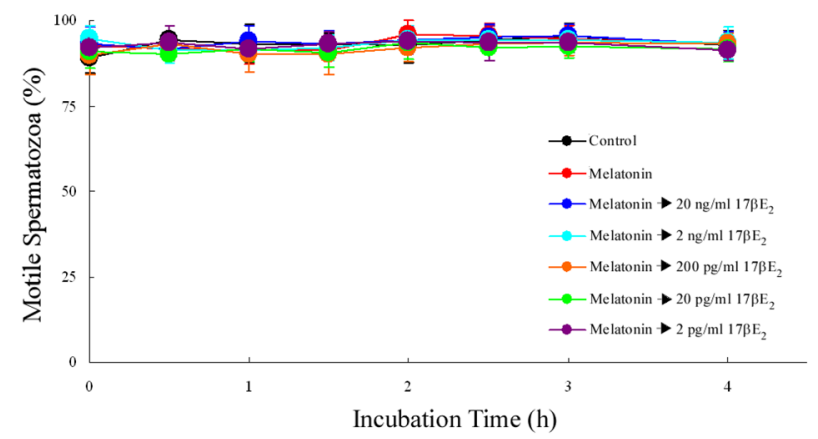

B

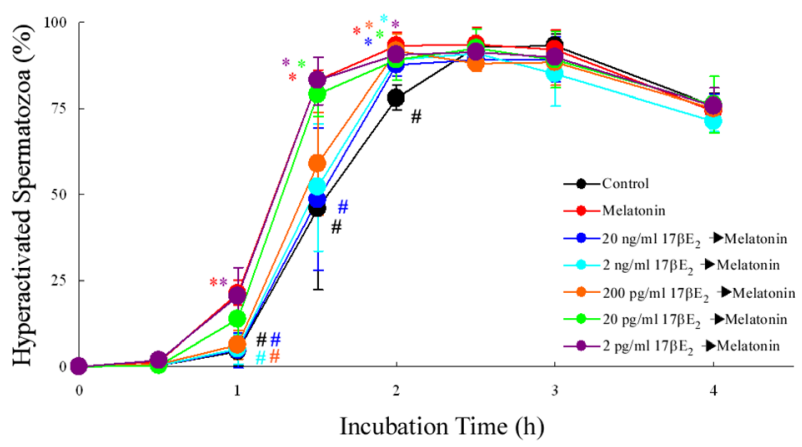

D

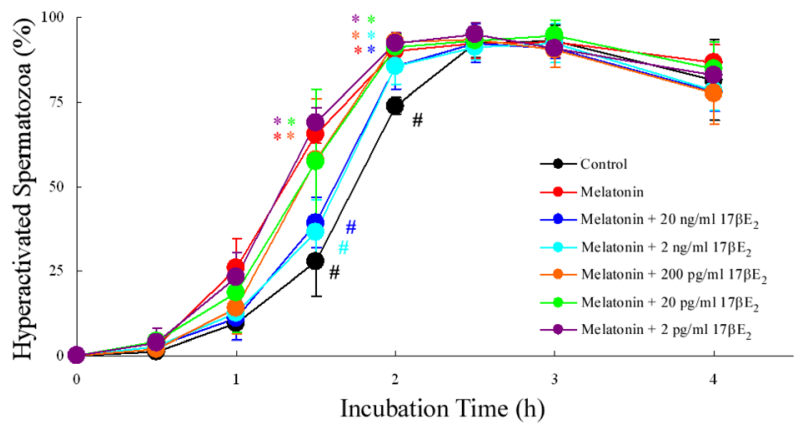

F

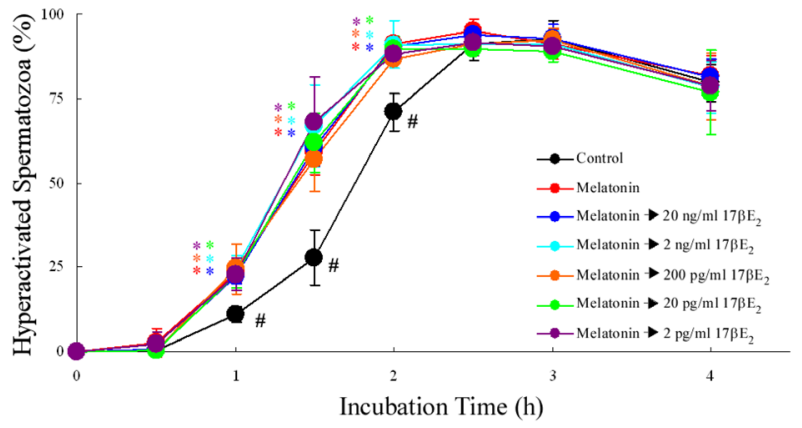

Fig. 5. Dose-dependent effects of $17 \beta \mathrm{E}_{2}$ on melatonin-enhanced hyperactivation. The percentages of motile (A, C, E) and hyperactivated (B, D, F) spermatozoa are shown $(\mathrm{A}, \mathrm{B})$ for when spermatozoa were exposed to melatonin after exposure to $17 \beta \mathrm{E}_{2},(\mathrm{C}, \mathrm{D})$ for when spermatozoa were simultaneously exposed to melatonin and $17 \beta \mathrm{E}_{2}$, and $(\mathrm{E}, \mathrm{F})$ for when spermatozoa were exposed to melatonin before exposure to $17 \beta \mathrm{E}_{2}$. In $\mathrm{A}$ and $\mathrm{B}$, after swim up, $17 \beta \mathrm{E}_{2}$ or vehicle was added to the mTALP medium containing motile spermatozoa. After incubation for 5 min, melatonin or vehicle was added to the same medium. In $\mathrm{C}$ and $\mathrm{D}$, after swim up, mixtures of melatonin and $17 \beta \mathrm{E}_{2}$ or vehicle were added to the mTALP medium containing motile spermatozoa. In $\mathrm{E}$ and $\mathrm{F}$, after swim up, melatonin or vehicle was added to the mTALP medium containing motile spermatozoa. After incubation for $5 \mathrm{~min}, 17 \beta \mathrm{E}_{2}$ or vehicle was added to the same medium. Data are expressed as the mean $\pm \mathrm{SD}$. (Control): mTALP medium with $0.2 \%$ (v/v) EtOH; (Melatonin): mTALP medium with added $1 \mathrm{nM}$ melatonin and $0.2 \%$ (v/v) EtOH; $\left(20 \mathrm{ng} / \mathrm{ml} 17 \beta \mathrm{E}_{2} \rightarrow\right.$ Melatonin, Melatonin

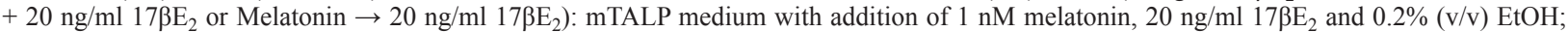

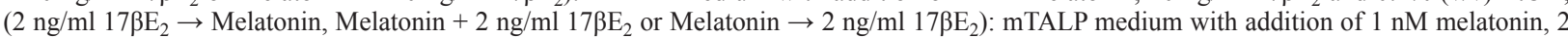

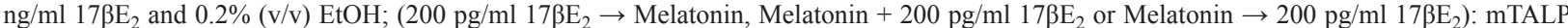
medium with addition of $1 \mathrm{nM}$ melatonin, $200 \mathrm{pg} / \mathrm{ml} 17 \beta \mathrm{E}_{2}$ and $0.2 \%(\mathrm{v} / \mathrm{v}) \mathrm{EtOH} ;\left(20 \mathrm{pg} / \mathrm{ml} 17 \beta \mathrm{E}_{2} \rightarrow\right.$ Melatonin, Melatonin $+20 \mathrm{pg} / \mathrm{ml} 17 \beta \mathrm{E}_{2}$

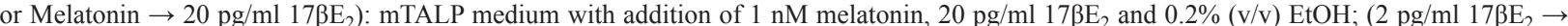
Melatonin, Melatonin $+2 \mathrm{pg} / \mathrm{ml}^{17} \beta \mathrm{E}_{2}$ or Melatonin $\left.\rightarrow 2 \mathrm{pg} / \mathrm{ml}_{17} 17 \mathrm{E}_{2}\right):$ mTALP medium with addition of $1 \mathrm{nM} \mathrm{melatonin,} 2 \mathrm{pg} / \mathrm{ml} 17 \beta \mathrm{E}_{2}$ and $0.2 \%$ (v/v) EtOH. *Significant difference compared with "Control" $(\mathrm{P}<0.05)$. \# Significant difference compared with "Melatonin" $(\mathrm{P}<0.05)$. Items with significant differences are indicated by symbols in the same color. $17 \beta \mathrm{E}_{2}, 17 \beta$-estradiol; EtOH, ethanol; mTALP medium, modified Tyrode's albumin lactate pyruvate medium. 
Finally, we observed sperm movement which were beforehand exposed to melatonin (Figs. 5E and 5F). Motile spermatozoa were exposed to $2 \mathrm{pg} / \mathrm{ml}$ to $20 \mathrm{ng} / \mathrm{ml} 17 \beta \mathrm{E}_{2}$ after exposure to $1 \mathrm{nM}$ melatonin for $5 \mathrm{~min}$. After addition of $17 \beta \mathrm{E}_{2}$ to the mTALP medium, spermatozoa were incubated for $4 \mathrm{~h}$. As shown in Figs. 5E and 5F, $2 \mathrm{pg} / \mathrm{ml}$ to $20 \mathrm{ng} / \mathrm{ml} 17 \beta \mathrm{E}_{2}$ did not affect the percentages of motile spermatozoa, hyperactivated spermatozoa and melatonin-enhanced hyperactivation

\section{Discussion}

Under capacitation conditions, sperm hyperactivation spontaneously occurs in vivo and in vitro [1, 3, 34-36]. Spontaneous hyperactivation time-dependently occurs during capacitation processes $[1,3$, 34-36]. Recent studies using human and hamster spermatozoa have shown that hyperactivation is enhanced by progesterone, melatonin and serotonin [5-7, 11-13]. Moreover, it has been also shown that progesterone-enhanced hyperactivation of hamster spermatozoa is suppressed by $17 \beta \mathrm{E}_{2}$ and $\mathrm{GABA}[8,10,18]$. Steroids of these hormones, such as progesterone and $17 \beta \mathrm{E}_{2}$, regulate sperm hyperactivation via non-genomic regulation $[2,7,8,37]$. In genomic regulation, generally, steroids bind to an intracellular receptor and induce gene expression, whereas in non-genomic regulation, the steroids bind to a membrane receptor and increase the concentration of a second messenger such as $\mathrm{Ca}^{2+}$ and/or cAMP [7, 9, 37]. In order to examine whether the regulatory effects of steroids are non-genomic, a BSA-conjugated steroid was used in previous studies [7, 8, 18] and in the present study (Fig. 4). Because BSA blocks entry of a BSA-conjugated steroid into the cell, the steroid is unable to bind to the intracellular receptor but can bind to the membrane receptor $[32,33]$. Therefore, it follows that the effects of a BSA-conjugated steroid will occur through non-genomic regulation. The results obtained from the present study (Fig. 4) suggest that enhancement of hyperactivation by melatonin was suppressed by $17 \beta \mathrm{E}_{2}$ through non-genomic regulation via a membrane ER.

Progesterone regulates hyperactivation through non-genomic regulation associated with two types of $\mathrm{Ca}^{2+}$ signaling: $\mathrm{Ca}^{2+}$ influx and release of $\mathrm{Ca}^{2+}$ from the $\mathrm{Ca}^{2+}$ store $[2,7,36-40]$. $\mathrm{Ca}^{2+}$ influx is induced by progesterone through the CatSper, which is a spermspecific $\mathrm{Ca}^{2+}$ channel located in the principal piece of the flagellum $[41,42]$. The release of $\mathrm{Ca}^{2+}$ from the $\mathrm{Ca}^{2+}$ store by progesterone is associated with both the PR and PLC [7]. Activation of PLC produces $\mathrm{IP}_{3}$ and diacylglycerol (DAG) from phosphatidylcholine and/or phosphatidylinositol. $\mathrm{IP}_{3}$ releases $\mathrm{Ca}^{2+}$ from the $\mathrm{IP}_{3} \mathrm{R}$-gated $\mathrm{Ca}^{2+}$ store localized at the base of flagellum [36-40]. $\mathrm{Ca}^{2+}$ and DAG regulate hyperactivation through activation of calmodulin-dependent protein kinase II and PKC $[9,43]$. After $\mathrm{Ca}^{2+}$ signaling is stimulated by progesterone, many tyrosine phosphorylations, especially the 80 - and $85-\mathrm{kDa}$ tyrosine phosphorylations of the fibrous sheath (FS), are increased and enhanced $[7,8,36]$. The $80-$ and $85 \mathrm{kDa}$ tyrosine phosphorylated FS proteins were identified as the A-kinase anchoring protein, which is a major component of the FS [44]. In general, tyrosine phosphorylation is a very important event during capacitation/hyperactivation [1, 2, 45-47]. It has been suggested that the 80 - and $85-\mathrm{kDa}$ tyrosine phosphorylations of the FS are closely associated with capacitation/hyperactivation [19, 46, 48]; and regulated by $\mathrm{Ca}^{2+} /$ calmodulin-dependent signals [49] and protein phosphatase 1 [50]. In non-genomic regulation, progesterone also activates adenylate cyclase to increase the cAMP concentration [37, $51,52]$. cAMP is an essential molecule for hyperactivation; and regulates the tyrosine phosphorylations, especially the 80 - and $85-\mathrm{kDa}$ tyrosine phosphorylations of the FS, through protein kinase A (PKA) signals $[1,45,47]$. Moreover, progesterone enhances hyperactivation through cAMP-PKA signals [9]. In contrast, $17 \beta \mathrm{E}_{2}$ suppresses progesterone-enhanced hyperactivation through non-genomic regulation associated with the ER and tyrosine dephosphorylations except for the 80- and 85-kDa tyrosine phosphorylations of the FS [8]. GABA also suppresses progesterone-enhanced hyperactivation via the $\mathrm{GABA}_{\mathrm{A}}$ receptor [18]. However, the regulatory mechanisms associated with suppression of progesterone-enhanced hyperactivation by $17 \beta \mathrm{E}_{2}$ and $\mathrm{GABA}$ are still unclear.

It has been shown that melatonin enhances hyperactivation of hamster spermatozoa via MT1 [11]. Moreover, in ram and human spermatozoa, it has been shown that melatonin increases sperm quality, motility, capacitation, fertility rate and the activities of antioxidant enzymes, and decreases nitric oxide (NO) [12, 53-56]. NO at low concentrations increases capacitation through a mitogen-activated protein kinase cascade and tyrosine phosphorylation, especially the 80 - and $85-\mathrm{kDa}$ tyrosine phosphorylations of the FS [57-59], whereas at high concentrations, it negatively affects sperm function $[58,60]$.

It has been shown that progesterone and $17 \beta \mathrm{E}_{2}$ bind to the head of hamster spermatozoa $[7,8]$, but it has not been shown where melatonin binds [11]. Ram spermatozoa have two melatonin receptors (MT1 and MT2), which are localized at various sites [61]. In humans, the MT1 receptor is located in the equatorial region of the sperm head [62]. In the present study, we did not show the regulatory mechanism of sperm hyperactivation caused by melatonin and $17 \beta \mathrm{E}_{2}$. One of the possibilities is the suppression of binding of melatonin to the melatonin receptor by $17 \beta \mathrm{E}_{2}$. Another is the suppression of intracellular melatonin signals by $17 \beta \mathrm{E}_{2}$. In a study investigating the regulation of sperm hyperactivation caused by progesterone and $17 \beta \mathrm{E}_{2}$, neither steroid interfered with binding to their respective receptors [8]. In contrast, one of the intracellular progesterone signal, such as tyrosine phosphorylation, was suppressed by $17 \beta \mathrm{E}_{2}$ [8]. We expect that $17 \beta \mathrm{E}_{2}$ affects intracellular melatonin signals in a manner similar to the regulatory mechanism of progesterone and $17 \beta \mathrm{E}_{2}$ because we previously noted that melatonin enhanced sperm hyperactivation through enhancement of tyrosine phosphorylations [11]. In future studies, we will show the detailed interaction between melatonin and $17 \beta \mathrm{E}_{2}$.

Progesterone enhances hamster sperm hyperactivation in a dosedependent manner [7], and progesterone-enhanced hyperactivation is dose-dependently suppressed by $17 \beta \mathrm{E}_{2}$ and $\mathrm{GABA}[8,10,18]$. The concentrations of progesterone and $17 \beta \mathrm{E}_{2}$ in blood and tissues fluctuate in association with the estrous or menstrual cycle [63]. The concentration of GABA in the female genital tract also fluctuates in association with the estrous cycle [64]. Therefore, we previously proposed that hamster sperm hyperactivation was regulated by balances among the concentrations of progesterone, $17 \beta \mathrm{E}_{2}$ and GABA $[8,10,18]$. Additionally, picomole or higher concentrations of melatonin enhance hamster sperm hyperactivation [11]. It was reported that picomole or higher concentrations of melatonin were 
detected from the follicular fluid of humans $[65,66]$. Based on these reports, we tried to examine the interactions among melatonin, $17 \beta \mathrm{E}_{2}$ and GABA; in the present study and found that $17 \beta \mathrm{E}_{2}$ suppressed melatonin-enhanced hyperactivation in a dose-dependent manner, whereas GABA did not (Figs. 1, 4 and 5). 17קE 2 suppressed melatoninenhanced hyperactivation through non-genomic regulation via the ER (Figs. 3 and 4). In another recent study [13], it was reported that serotonin also enhanced hamster sperm hyperactivation. These results and results of previous studies $[7,8,10,11,13,18]$ suggest that in the hamster, progesterone, melatonin and serotonin act as enhancers of hyperactivation; and that $17 \beta \mathrm{E}_{2}$ and GABA act as suppressors. Although we did not investigate relationships among the regulation by progesterone, $17 \beta \mathrm{E}_{2}$ and $\mathrm{GABA}$, the regulation by melatonin and $17 \beta \mathrm{E}_{2}$ and the regulation by serotonin, we propose that materials in the follicular fluid, such as progesterone, melatonin, serotonin, $17 \beta \mathrm{E}_{2}$ and $\mathrm{GABA}$, regulate hyperactivation of hamster spermatozoa.

It has been suggested that spermatozoa are capacitated/hyperactivated in response to changes in the environment of the oviduct $[7,8$, $10,11,13,18,35]$. During capacitation/hyperactivation of hamster spermatozoa, progesterone, melatonin and serotonin act as enhancers and $17 \beta \mathrm{E}_{2}$, and GABA acts as a suppressor [7, 8, 10, 11, 13, 18]. Although GABA acts as a suppressor of hamster spermatozoa [18], it is an enhancer of other mammalian spermatozoa such as those of humans, rams and rats [14-17]. Because the concentrations of hormones vary during the female's estrous cycle [63], it seems that mammalian spermatozoa are capacitated/hyperactivated in response to the changing environment of the oviduct $[8,10,18,35]$. In particular, the results of the present study suggest that mammalian spermatozoa, at least hamster spermatozoa, are capacitated/hyperactivated according to changing concentrations of melatonin and $17 \beta \mathrm{E}_{2}$ in the oviduct.

There are two regulatory mechanisms of hyperactivation in mammalian or at least hamster spermatozoa. One is a spontaneous regulatory mechanism associated with $\mathrm{Ca}^{2+}, \mathrm{HCO}_{3}^{-}$, protein phosphorylations and so on $[1-3,45,47]$. Another is a ligand-dependent modulatory mechanism associated with progesterone, $17 \beta \mathrm{E}_{2}$, melatonin, serotonin and GABA [7-11, 13, 18] (Fig. 1). In both mechanisms, $\mathrm{Ca}^{2+}$ signals, cAMP-PKA signals and tyrosine phosphorylations are very important $[1-3,7-9,19,45,47]$. However, the ligand-dependent modulatory mechanism differs from the spontaneous regulatory mechanism because hyperactivation itself is not suppressed by inhibition of the ligand-dependent modulatory mechanism [7-9, 11, 13, 18] (Fig. 1).

In conclusion, we propose that spermatozoa start to be capacitated/ hyperactivated through the spontaneous regulatory mechanism in the oviduct. After that, it seems that capacitation/hyperactivation of spermatozoa is enhanced through a modulatory mechanism associated with changes in the environment of the oviduct.

\section{References}

1. Yanagimachi R. Mammalian fertilization. In: Knobil E, Neill JD (ed.), The Physiology of Reproduction Vol. 2, 2nd ed. New York: Raven Press; 1994: 189-317.

2. Fujinoki M. Non-genomic regulation of mammalian sperm hyperactivation. Reprod Med Biol 2009; 8: 47-52. [CrossRef]

3. Mohri H, Inaba K, Ishijima S, Baba SA. Tubulin-dynein system in flagellar and ciliary movement. Proc Jpn Acad Ser B 2012; 88: 397-415.

4. Alasmari W, Barratt CLR, Publicover SJ, Whalley KM, Foster E, Kay V, Martins da Silva S, Oxenham SK. The clinical significance of calcium-signalling pathways mediating human sperm hyperactivation. Hum Reprod 2013; 28: 866-876. [Medline] [CrossRef]
5. Sueldo CE, Oehninger S, Subias E, Mahony M, Alexander NJ, Burkman LJ, Acosta AA. Effect of progesterone on human zona pellucida sperm binding and oocyte penetrating capacity. Fertil Steril 1993; 60: 137-140. [Medline]

6. Yang J, Serres C, Philibert D, Robel P, Baulieu EE, Jouannet P. Progesterone and RU486: opposing effects on human sperm. Proc Natl Acad Sci USA 1994; 91: 529-533. [Medline] [CrossRef]

7. Noguchi T, Fujinoki M, Kitazawa M, Inaba N. 2008 Regulation of hyperactivation of hamster spermatozoa by progesterone. Reprod Med Biol 2008; 7: 63-74. [CrossRef]

8. Fujinoki M. Suppression of progesterone-enhanced hyperactivation in hamster spermatozoa by estrogen. Reproduction 2010; 140: 453-464. [Medline] [CrossRef]

9. Fujinoki M. Progesterone-enhanced sperm hyperactivation through $\mathrm{IP}_{3}-\mathrm{PKC}$ and $\mathrm{PKA}$ signals. Reprod Med Biol 2013; 12: 27-33. [CrossRef]

10. Fujinoki M. Regulation and disruption of hamster sperm hyperactivation by progesterone, 17ß-estradiol and diethylstilbestrol. Reprod Med Biol 2014; 13: 143-152. [CrossRef]

11. Fujinoki M. Melatonin-enhanced hyperactivation of hamster sperm. Reproduction 2008; 136: 533-541. [Medline] [CrossRef]

12. du Plessis SS, Hagenaar K, Lampiao F. The in vitro effects of melatonin on human sperm function and its scavenging activities on NO and ROS. Andrologia 2010; 42: 112-116. [Medline] [CrossRef]

13. Fujinoki M. Serotonin-enhanced hyperactivation of hamster sperm. Reproduction 2011; 142: 255-266. [Medline] [CrossRef]

14. Calogero AE, Hall J, Fishel S, Green S, Hunter A, D'Agata R. Effects of $\gamma$-aminobutyric acid on human sperm motility and hyperactivation. Mol Hum Reprod 1996; 2: 733-738. [Medline] [CrossRef]

15. de las Heras MA, Valcarcel A, Perez LJ. In vitro capacitating effect of gamma-aminobutyric acid in ram spermatozoa. Biol Reprod 1997; 56: 964-968. [Medline] [CrossRef]

16. Ritta MN, Calamera JC, Bas DE. Occurrence of GABA and GABA receptors in human spermatozoa. Mol Hum Reprod 1998; 4: 769-773. [Medline] [CrossRef]

17. Jin J-Y, Chen W-Y, Zhou CX, Chen Z-H, Yu-Ying Y, Ni Y, Chan HC, Shi Q-X. Activation of $\mathrm{GABA}_{\mathrm{A}}$ receptor/ $\mathrm{Cl}^{-}$channel and capacitation in rat spermatozoa: $\mathrm{HCO}_{3}{ }^{-}$and $\mathrm{Cl}^{-}$are essential. Syst Biol Reprod Med 2009; 55: 97-108. [Medline] [CrossRef]

18. Kon H, Takei GL, Fujinoki M, Shinoda M. Suppression of progesterone-enhanced hyperactivation in hamster spermatozoa by $\gamma$-aminobutyric acid. J Reprod Dev 2014; 60: 202-209. [Medline] [CrossRef]

19. Fujinoki M, Suzuki T, Takayama T, Shibahara H, Ohtake H. Profiling of proteins phosphorylated or dephosphorylated during hyperactivation via activation on hamster spermatozoa. Reprod Med Biol 2006; 5: 123-135.

20. Maleszewski M, Kline D, Yanagimachi R. Activation of hamster zona-free oocytes by homologous and heterologous spermatozoa. J Reprod Fertil 1995; 105: 99-107. [Medline] [CrossRef]

21. Fujinoki M, Ohtake H, Okuno M. Serine phosphorylation of flagellar proteins associated with the motility activation of hamster spermatozoa. Biomed Res 2001; 22: 45-58. [CrossRef]

22. Littlefield BA, Gurpide E, Markiewicz L, McKinley B, Hochberg RB. A simple and sensitive microtiter plate estrogen bioassay based on stimulation of alkaline phosphatase in Ishikawa cells: estrogenic action of delta 5 adrenal steroids. Endocrinology 1990; 127: 2757-2762. [Medline] [CrossRef]

23. Bhavnani BR. Pharmacokinetics and pharmacodynamics of conjugated equine estrogens: chemistry and metabolism. Proc Soc Exp Biol Med 1998; 217: 6-16. [Medline] [CrossRef]

24. Lippman M, Bolan G, Huff K. The effects of estrogens and antiestrogens on hormoneresponsive human breast cancer in long-term tissue culture. Cancer Res 1976; 36: 4595-4601. [Medline]

25. Coezy E, Borgna JL, Rochefort H. Tamoxifen and metabolites in MCF7 cells: correlation between binding to estrogen receptor and inhibition of cell growth. Cancer Res 1982; 42: 317-323. [Medline]

26. Reddel RR, Murphy LC, Sutherland RL. Effects of biologically active metabolites of tamoxifen on the proliferation kinetics of MCF-7 human breast cancer cells in vitro. Cancer Res 1983; 43: 4618-4624. [Medline]

27. Daniel CP, Gaskell SJ, Bishop H, Nicholson RI. Determination of tamoxifen and an hydroxylated metabolite in plasma from patients with advanced breast cancer using gas chromatography-mass spectrometry. J Endocrinol 1979; 83: 401-408. [Medline] [CrossRef]

28. Adam HK, Douglas EJ, Kemp JV. The metabolism of tamoxifen in human. Biochem Pharmacol 1979; 28: 145-147. [Medline] [CrossRef]

29. Daniel P, Gaskell SJ, Bishop H, Campbell C, Nicholson RI. Determination of tamoxifen and biologically active metabolites in human breast tumours and plasma. Eur J Cancer Clin Oncol 1981; 17: 1183-1189. [Medline] [CrossRef]

30. O'Brian CA, Liskamp RM, Solomon DH, Weinstein IB. Inhibition of protein kinase C by tamoxifen. Cancer Res 1985; 45: 2462-2465. [Medline]

31. O'Brian CA, Kuo JF. Protein kinase C inhibitors. In: Kuo JF (ed.), Protein Kinase C. Oxford University Press; 1994: 96-129. 
32. Luconi M, Muratori M, Forti G, Baldi E. Identification and characterization of a novel functional estrogen receptor on human sperm membrane that interferes with progesterone effects. J Clin Endocrinol Metab 1999; 84: 1670-1678. [Medline] [CrossRef]

33. Baldi E, Luconi M, Muratori M, Forti G. A novel functional estrogen receptor on human sperm membrane interferes with progesterone effects. Mol Cell Endocrinol 2000; 161: 31-35. [Medline] [CrossRef]

34. Suarez SS, Ho HC. Hyperactivated motility in sperm. Reprod Domest Anim 2003; 38: 119-124. [Medline] [CrossRef]

35. Coy P, García-Vázquez FA, Visconti PE, Avilés M. Roles of the oviduct in mammalian fertilization. Reproduction 2012; 144: 649-660. [Medline] [CrossRef]

36. Ho HC, Suarez SS. Hyperactivation of mammalian spermatozoa: function and regulation. Reproduction 2001; 122: 519-526. [Medline] [CrossRef]

37. Baldi E, Luconi M, Muratori M, Marchiani S, Tamburrino L, Forti G. Nongenomic activation of spermatozoa by steroid hormones: facts and fictions. Mol Cell Endocrinol 2009; 308: 39-46. [Medline] [CrossRef]

38. Ho HC, Granish KA, Suarez SS. Hyperactivated motility of bull sperm is triggered at the axoneme by $\mathrm{Ca}^{2+}$ and not cAMP. Dev Biol 2002; 250: 208-217. [Medline] [CrossRef]

39. Ho HC, Suarez SS. An inositol 1,4,5-trisphosphate receptor-gated intracellular $\mathrm{Ca}^{2+}$ ) store is involved in regulating sperm hyperactivated motility. Biol Reprod 2001; 65: 1606-1615. [Medline] [CrossRef]

40. Ho HC, Suarez SS. Characterization of the intracellular calcium store at the base of the sperm flagellum that regulates hyperactivated motility. Biol Reprod 2003; 68: 1590-1596. [Medline] [CrossRef]

41. Lishko PV, Botchkina IL, Kirichok Y. Progesterone activates the principal $\mathrm{Ca}^{2+}$ channel of human sperm. Nature 2011; 471: 387-391. [Medline] [CrossRef]

42. Strünker T, Goodwin N, Brenker C, Kashikar ND, Weyand I, Seifert R, Kaupp UB. The CatSper channel mediates progesterone-induced $\mathrm{Ca}^{2+}$ influx in human sperm. Nature 2011; 471: 382-386. [Medline] [CrossRef]

43. Ignotz GG, Suarez SS. Calcium/calmodulin and calmodulin kinase II stimulate hyperactivation in demembranated bovine sperm. Biol Reprod 2005; 73: 519-526. [Medline] [CrossRef]

44. Carrera A, Gerton GL, Moss SB. The major fibrous sheath polypeptide of mouse sperm: structural and functional similarities to the A-kinase anchoring proteins. Dev Biol 1994; 165: 272-284. [Medline] [CrossRef]

45. Visconti PE, Kopf GS. Regulation of protein phosphorylation during sperm capacitation. Biol Reprod 1998; 59: 1-6. [Medline] [CrossRef]

46. Visconti PE, Bailey JL, Moore GD, Pan D, Olds-Clarke P, Kopf GS. Capacitation of mouse spermatozoa. I. Correlation between the capacitation state and protein tyrosine phosphorylation. Development 1995; 121: 1129-1137. [Medline]

47. Visconti PE, Galantino-Homer H, Moore GD, Bailey JL, Ning X, Fornes M, Kopf GS. The molecular basis of sperm capacitation. J Androl 1998; 19: 242-248. [Medline]

48. Fujinoki M, Ohtake H, Okuno M. Tyrosine phosphorylation and dephosphorylation associated with motility of hamster spermatozoa. Biomed Res 2001; 22: 147-155. [CrossRef]

49. Carrera A, Moos J, Ning XP, Gerton GL, Tesarik J, Kopf GS, Moss SB. Regulation of protein tyrosine phosphorylation in human sperm by a calcium/calmodulin-dependent mechanism: identification of A kinase anchor proteins as major substrates for tyrosine phosphorylation. Dev Biol 1996; 180: 284-296. [Medline] [CrossRef]
50. Suzuki T, Fujinoki M, Shibahara H, Suzuki M. Regulation of hyperactivation by PPP2 in hamster spermatozoa. Reproduction 2010; 139: 847-856. [Medline] [CrossRef]

51. Harrison DA, Carr DW, Meizel S. Involvement of protein kinase A and A kinase anchoring protein in the progesterone-initiated human sperm acrosome reaction. Biol Reprod 2000; 62: 811-820. [Medline] [CrossRef]

52. Gellersen B, Fernandes MS, Brosens JJ. Non-genomic progesterone actions in female reproduction. Hum Reprod Update 2009; 15: 119-138. [Medline] [CrossRef]

53. Casao A, Mendoza N, Pérez-Pé R, Grasa P, Abecia J-A, Forcada F, Cebrián-Pérez JA, Muino-Blanco T. Melatonin prevents capacitation and apoptotic-like changes of ram spermatozoa and increases fertility rate. $J$ Pineal Res 2010; 48: 39-46. [Medline] [CrossRef]

54. Espino J, Bejarano I, Ortiz A, Lozano GM, García JF, Pariente JA, Rodríguez AB. Melatonin as a potential tool against oxidative damage and apoptosis in ejaculated human spermatozoa. Fertil Steril 2010; 94: 1915-1917. [Medline] [CrossRef]

55. Ortiz A, Espino J, Bejarano I, Lozano GM, Monllor F, García JF, Pariente JA, Rodríguez AB. High endogenous melatonin concentrations enhance sperm quality and short-term in vitro exposure to melatonin improves aspects of sperm motility. J Pineal Res 2011; 50: 132-139. [Medline]

56. Succu S, Berlinguer F, Pasciu V, Satta V, Leoni GG, Naitana S. Melatonin protects ram spermatozoa from cryopreservation injuries in a dose-dependent manner. $J$ Pineal Res 2011; 50: 310-318. [Medline] [CrossRef]

57. O'Flaherty C, de Lamirande E, Gagnon C. Positive role of reactive oxygen species in mammalian sperm capacitation: triggering and modulation of phosphorylation events. Free Radic Biol Med 2006; 41: 528-540. [Medline] [CrossRef]

58. Agarwal A, Makker K, Sharma R. Clinical relevance of oxidative stress in male factor infertility: an update. Am J Reprod Immunol 2008; 59: 2-11. [Medline] [CrossRef]

59. de Lamirande E, O'Flaherty C. Sperm activation: role of reactive oxygen species and kinases. Biochim Biophys Acta 2008; 1784: 106-115. [Medline] [CrossRef]

60. Iwasaki A, Gagnon C. Formation of reactive oxygen species in spermatozoa of infertile patients. Fertil Steril 1992; 57: 409-416. [Medline]

61. Casao A, Gallego M, Abecia JA, Forcada F, Pérez-Pé R, Muiño-Blanco T, CebriánPérez JA. Identification and immunolocalisation of melatonin $\mathrm{MT}\left({ }_{1}\right)$ and $\mathrm{MT}\left({ }_{2}\right)$ receptors in Rasa Aragonesa ram spermatozoa. Reprod Fertil Dev 2012; 24: 953-961. [Medline] [CrossRef]

62. Dimitrov R, Georgiev G, Todorov P, Dimitrov Y, Konakchieva R. Membrane melatonin receptor type MT1 expression in human ejaculated spermatozoa. Compt rend Acad bulg Sci 2012; 65: 947-952.

63. Schillo KK. Reproductive Physiology of Mammals: From Farm to Field and Beyond. New York: Delmar; 2009.

64. Louzan P, Gallardo MGP, Tramezzani JH. Gamma-aminobutyric acid in the genital tract of the rat during the oestrous cycle. J Reprod Fertil 1986; 77: 499-504. [Medline] [CrossRef]

65. Brzezinski A, Seibel MM, Lynch HJ, Deng MH, Wurtman RJ. Melatonin in human preovulatory follicular fluid. J Clin Endocrinol Metab 1987; 64: 865-867. [Medline] [CrossRef]

66. Rönnberg L, Kauppila A, Leppäluoto J, Martikainen H, Vakkuri O. Circadian and seasonal variation in human preovulatory follicular fluid melatonin concentration. $\mathrm{J}$ Clin Endocrinol Metab 1990; 71: 492-496. [Medline] [CrossRef] 